\title{
Komunitas Ambengan Sebagai Gerakan Multikulturalisme Mereduksi Akar Konflik di Lampung Timur
}

\author{
Lukman Hakim \\ Waroeng Batja Desa Binakarya Utama Kecamatan Putra Rumbia \\ uman.alhakim2@gmail.com
}

\begin{abstract}
Abstrak
Komunitas Dusun Ambengan atau biasa disebut Ambengan adalah forum budaya yang didirikan oleh Syamsul Arifin atau akrab dipanggil "Cak Sul". Ambengan adalah gerakan ikhtiar kebudayaan yang melestarikan dialog antar agama, etnis, golongan untuk mau berkumpul membahas keragaman kultural yang dimiliki oleh suku-suku yang hidup di tanah Lampung. Maiyah Dusun Ambengan berusaha melakukan pelestarian budaya lokal dan berupaya mereduksi konflik yang ada di Lampung. Ambengan berupaya membangun pelestarian budaya sebagai kearifan lokal dan keragaman bangsa. Maka peneliti melakukan penelitian yang berjudul "Budaya Ambengan Sebagai Gerakan Multikulturalisme Mereduksi Akar Konflik Di Lampung Timur". Jenis penelitian dikategorikan penelitian lapangan (field research) yaitu penelitian yang dilakukan di kancah atau medan terjadinya gejala. Sifat penelitian ini adalah penelitian deskriptifkualitatif, yaitu sebuah penelitian yang berusaha mengungkap keadaan yang bersifat alamiah secara holistik. Sumber data dalam penelitian ini adalah sumber data primer dan sekunder. Metode pengumpulan data dalam peneltian ini adalah observasi, wawancara semi struktur dan dokumentasi. Kebudayaan menjadi sesuatu yang sangat penting bagi komunitas satu maupun komunitas lain diluarnya. Bagi komunitas lain diluarnya, hal ini menjadi "pintu" untuk memasuki dan mempelajari komunitas tertentu. Kebudayaan menjadi dasar untuk bertingkah laku dalam masyarakat dan juga untuk menghindari konflik. Namun, apabila konflik tidak dapat dihindarkan maka nilai-nilai kebudayaan akan kembali digunakan sebagai proses penyelesaian masalah. Komunitas Ambengan adalah komunitas yang menggunakan kebudayaan sebagai sarana untuk membuka ruang dialog yang pada akhirnya memberikan pemahaman tentang multikulturalisme dan dapat dijadikan sebagai upaya mereduksi potensi konflik yang ada di Lampung Timur.
\end{abstract}

Kata Kunci: Multikulturalisme, Ambengan, Reduksi Konflik.

\section{Pendahuluan}

Agama, secara mendasar dan umum, dapat diartikan sebagai seperangkat aturan dan peraturan yang mengatur hubungan manusia dengan dunia gaib, khususnya dengan Tuhannya, mengatur hubungan manusia dengan sesama manusia, dan manusia dengan lingkungannya. ${ }^{1}$ Maka agama dalam pandangan Clifford Geertz juga bisa dimaknai sebagai sistem budaya. ${ }^{2}$

Keyakinan masing-masing agama cenderung dapat dieksploitasi dalam konflik antar agama ataupun konflik lain yang akhirnya dapat melibatkan agama. Misalnya doktrin gereja 'extra exclesia nula solum' (di luar gereja tidak ada

\footnotetext{
1Supardi Suparlan, kata pengantar dalam Buku, Agama: Dalam Analisa Dan Interpretasi Sosiologis (Di-edit oleh Ronald Robertson). (Jakarta: Rajawali, 1988).

2 Geertz, C, Religion as a Cultural System. Dalam Anthropological Approaches to the Study of Religion. (Di-edit oleh Michael Banton). (London: Tavistock, 1966)
} 
keselamatan) dan doktrin Islam 'waman yabtaghi ghoira al-Islama dinan fala yuqbalu minhu' (barang siapa yang mencari agama yang kecuali Islam maka tidak akan diterima). Multikulturalisme sangat penting sebagai paham tentang kultur yang bermacam-macam yang menekankan kesenjangan dan kesetaraan budayabudaya lokal dengan tidak mengabaikan hak-hak keberadaan budaya yang ada. ${ }^{3}$ Tantangan multikulturalisme adalah bagaimana pelaku agama mampu menempatkan perbedaan keyakinan itu menjadi keragaman yang rukun di tengah masyarakat. Maka isu inklusifitas (keterbukaan) menjadi penting dalam membangun multikulturalisme di masyarakat. ${ }^{4}$

Konsep kebudayaan menurut Koentjaraningrat dalam konsep kebudayaan diartikan sebagai wujudnya, yaitu mencakup keseluruhan dari: (1) gagasan; (2) kelakuan; dan (3) hasil-hasil kelakuan. Dengan menggunakan definisi ini maka seseorang pengamat atau peneliti akan melihat bahwa segala sesuatu yang ada dalam pikirannya, yang dilakukan dan yang dihasilkan oleh kelakuan atau perilaku manusia adalah kebudayaan. ${ }^{5}$

Islam nusantara misalnya mengalami; apa yang disebut oleh Homi K. Bhabba sebagai mimicry; semacam peniru budaya atau anex aggerated copying of language, culture, manners, and ideas, dalam bahasa Bhabba. ${ }^{6}$ Pencaplokan budaya itu, berbentuk artikulasi ganda (double articulation): sesuatu yang hampir sama, namun tak serupa. Di sisi lain, mimicry juga berarti mencemooh (mockery). Mimikri, jelas Ahmad Baso, selalu dibentuk inter dicta, yakni diantara persilangan antara apa yang diketahui dan diperbolehkan (untuk diketahui) dan yang bisa diketahui, tetapi terlarang dan harus ditutup rapat. ${ }^{7}$

Akulturasi budaya juga terjadi antara masyarakat suku asli Lampung dengan suku pendatang seperti Jawa, Bali, Minang, Batak dan lainnya. Kebudayaan Lampung yang menjadi adat istiadat masyarakat Lampung mulai tercampuri dengan adat istiadat lain. Dalam kehidupan masyarakat kota misalnya, akulturasi budaya sangat terjadi dimana para kelompok mudah membaur dengan melepaskan ego-komunalnya. Lain halnya pada masyarakat perbatasan antar suku yang cenderung mudah mengalami konflik. Misal saja konflik Balinuraga ${ }^{8}$ Lampung Selatan, Konflik Bumijawa Lampung Timur,

3 Parekh, B, Rethinking Multiculturalism: Cultural diversity and Political Theory, (MacMillan: Press Ltd, 2000).

${ }^{4}$ Kymlicka, W, Multicultural Citicenship: Liberal theory of Minority Rights, (Oxford: Clarendon Press, 1995).

${ }^{5}$ Koentjaraningrat, Ilmu Antropologi. (Jakarta: Bhratara, 1988)

6 David Huddart, Homi K. Bhabha, (London \& New York, Routledge, 2006), h. 39

${ }^{7}$ Ahmad Baso, Islam Pasca Kolonial: Perselingkuhan Agama, Kolonialisme, dan Liberalisme, (Bandung: Mizan, 2005), h. 68

8 Bethra Ariestha, Akar Konflik Kerusuhan Antar Etnik Di Lampung Selatan (Studi Pada Kerusuhan Antar Etnik Lampung dan Etnik Bali di Lampung Selatan). Skripsi. Jurusan Psikologi Fakultas Ilmu Pendidikan Universitas Negeri Semarang (2013). 
Konflik Padang Ratu, Lampung Tengah9 dan konflik lainnya. Ali Humaedi menyebut konflik Balinuraga sebagai kegagalan akulturasi budaya dan agama ${ }^{10}$ di etnis Lampung dan Bali. ${ }^{11}$

Faktanya, unsur kebudayaan luar ada yang diterima dan ada yang tidak diterima. Unsur-unsur kebudayaan dari luar yang mudah diterima oleh sebuah masyarakat biasanya meliputi; alat-alat fisik yang mudah ditiru penggunaannya, unsur-unsur yang terbukti bermanfaat untuk masyarakat pengguna dan unsurunsur yang mudah disesuaikan dengan keadaan masyarakat yang menerima unsur-unsur tadi. Sedangkan unsur-unsur kebudayaan luar yang sulit diterima adalah; unsur-unsur yang memiliki fungsi yang telah terjaring luas di kalangan masyarakat, unsur-unsur yang telah dipelajari pada tingkat terdahulu dalam proses sosialisasi oleh individu-individu dalam masyarakat dan unsur yang berhubungan dengan religi atau kepercayaan ${ }^{12}$.

Komunitas Dusun Ambengan atau biasa disebut Ambengan adalah forum budaya yang didirikan oleh Syamsul Arifin atau akrab dipanggil "Cak Sul". Ambengan adalah gerakan ikhtiar kebudayaan yang melestarikan dialog antar agama, etnis, golongan untuk mau berkumpul membahas keragaman kultural yang dimiliki oleh suku-suku yang hidup di tanah Lampung.

Terkait dengan ini, Ambengan adalah bagian dari tradisi 'Maiyahan'. ${ }^{13}$ Maiyah diisi dengan sholawat, wirid, doa, kesenian musik, dialog budaya. Orang maiyah menurut Cak Nun adalah orang hidup yang menghadapi kehidupan dengan tuntas menjalaninya, merenungi, menghayati, menangisi dan menertawakannya. Ambengan adalah bagian penerus dari tradisi musik Kiai Kanjeng dan Cak Nun di Yogyakarta yang selama ini menghidupkan dialog Kebudayaan. ${ }^{14}$ Sebagaimana Jamaah Maiyah asuhan Cak Nun seperti Padhangmbulan Jombang berlangsung setiap tanggal 15 bulan Jawa atau tepat pada saat malam bulan purnama. Mocopat Syafaat Yogyakarta dilaksanakan setiap tanggal 17. Kenduri Cinta Jakarta berlangsung setiap hari Jumat minggu kedua setiap bulannya. Dan Gambang Syafaat di Semarang setiap tanggal 25. Bangbang Wetan Surabaya berlangsung sehari sesudah Padhangmbulan. ${ }^{15}$

\footnotetext{
9 Putut Ary Sadewo, Dinamika Konflik Agraria dalam kehidupan sosial Masyarakat Sendangayu dan Surabaya Kecamatan Padangratu, (Tesis Pascasarjana Pendidikan IPS Fakultas Keguruan dan Ilmu Pendidikan Universitas Lampung, 2014).

10 M. Alie Humaedi, Kegagalan Akulturasi Budaya Dan Isu Agama Dalam Konflik Lampung, Jurnal “Analisa” Volume 21 Nomor 02 Desember 2014, h.149-162

11 M. Alie Humaedi. Konflik Komunal Lampung-Bali: Anatomi dan Pemicu Konflik. Laporan Penelitian. (Jakarta: LIPI, 2013)

12 Koentajaraningrat, Pengantar Ilmu Antropologi, Jakarta: Aksara Baru, 1980, h. 146

13 Emha Ainun Najib, Orang Maiyah: Terang dalam kegelapan Kaya dalam Kemiskinan, (Yogyakarta: Progress, 2007)

14 Saputra, P. R. Spiritual Journey: Pemikiran dan Permenungan Emha Ainun Nadjib. (Jakarta: Kompas, 2012)

15 Jadwal Maiyah, di unduh tanggal 17 februari 2016 melalui https://www.caknun.com/jadwal/
}

RI'AYAH, Vol. 02, No. 01 Januari-Juni 2017 
Ambengan melakukan pelestarian kebudayaan di tengah-tengah masyarakat dengan pertunjukan musik, dialog beragam etnis dan agama, diskusi tematik, pertunjukkan seni tari, dan lain sebagainya. ${ }^{16}$ Sebagaimana Reportase kegiatan maiyah, kegiatan Ambengan dapat diakses melalui website kenduricinta.com dan juga website Ambengan di alamat ambengan.co.

Maiyah Dusun Ambengan adalah salah satu simpul Maiyah yang ada di Lampung. Karena Syamsul Arifin atau Cak Sul adalah orang yang pernah terlibat aktif dalam acara maiyah yang diadakan oleh Emha Ainun Najib saat berada di Yogyakarta. Jadi, Maiyah Dusun Ambengan adalah replikasi dari Maiyah yang dilakukan oleh Cak Nun, dan di Lampung dipimpin oleh Syamsul Arifin.

Maiyah Dusun Ambengan adalah sebuah acara diskusi kebudayaan, yang digelar rutin bulanan setiap hari Sabtu malam di minggu ke-2 tiap bulannya. Berlangsung mulai jam 20.00 WIB sd. selesai, bertempat di Rumah Hati Lampung Dusun 4 Margototo Kecamatan Metro Kibang Lampung Timur.

Kegiatan ini merupakan ajang belajar bersama yang bertitel "Sinau Kebudayaan". Menyuguhkan kajian-kajian beragam tematik keilmuan, persoalan-persoalan real keseharian masyarakat terkait sosial, ekonomi, seni budaya, dan keagamaan.

Maiyah Dusun Ambengan berusaha melakukan pelestarian budaya lokal dan berupaya mereduksi konflik yang ada di Lampung. Ambengan berupaya membangun pelestarian budaya sebagai kearifan lokal dan keragaman bangsa. Pelestarian merupakan usaha memelihara untuk kurun waktu yang sangat lama maka diperlukan dikembangkan pelestarian sebagai upaya yang berkelanjutan (sustainable). Pelestarian harus hidup dan berkembang di masyarakat. Pelestarian harus diperjuangkan oleh masyarakat luas. ${ }^{17}$

\section{Konsep Multikulturalisme \\ Pengertian Multikulturalisme}

Multikulturalisme berasal dari kata multi (plural) dan kultural (tentang budaya). Multikulturalisme mengisyaratkan pengakuan terhadap realitas keragaman kultural, yang berarti mencakup baik keberagaman tradisional seperti keberagaman suku, ras, ataupun agama, maupun keberagaman bentuk-bentuk kehidupan (subkultur) yang terus bermunculan di setiap tahap sejarah kehidupan masyarakat. 18 Februari 2016

16 http://www.ambengan.co/2016/01/mukadimah-reog-and-roll.html di unduh 17

17 Hadiwinoto, S. "Beberapa Aspek Pelestarian Warisan Budaya". Makalah disampaikan pada Seminar Pelestarian dan Pengembangan Masjid Agung Demak, di Demak, 17 Januari 2002, h. 30

${ }^{18}$ Ana Irhandayaningsih, "Kajian Filosofis Terhadap Multikulturalisme Indonesia" h. 2

RI'AYAH, Vol. 02, No. 01 Januari-Juni 2017 
Istilah "Multikulturalisme" tidaklah memadai jika hanya dipahami secara harfiah sebagai "paham banyak budaya". Multikulturalisme mencakup gagasan, cara pandang, kebijakan, penyikapan dan tindakan, oleh masyarakat suatu negara, yang majemuk dari segi etnis, budaya, agama, dan sebagainya, namun mempunyai cita-cita untuk mengembangkan semangat kebangsaan yang sama dan mempunyai kebanggaan untuk mempertahankan kemajemukan tersebut. ${ }^{19}$

Multikulturalisme secara sederhana dapat dikatakan pengakuan atas pluralisasi budaya. Pluralisme budaya bukanlah suatu yang "given" tetapi merupakan suatu proses internalisasi nilai-nilai di dalam suatu komunitas. ${ }^{20}$ Menurut Suparlan, multikulturalisme yaitu sebuah ideologi yang mengakui dan mengagungkan perbedaan dalam kesederajatan, baik secara individual maupun secara kebudayaan. Dalam model multikulturalisme ini, sebuah masyarakat dilihat mempunyai sebuah kebudayaan yang berlaku umum dalam masyarakat tersebut yang coraknya seperti sebuah mosaik. Mosaik mencakup semua kebudayaan dari masyarakat-masyarakat lebih kecil yang membentuk terwujudnya masyarakat lebih besar, dan kemudian menjadi kebudayaan seperti sebuah mosaik tersebut. ${ }^{21}$

Berdasarkan pemaparan-pemaparan di atas dapat dipahami bahwa multikulturalisme adalah sebuah gagasan, cara pandang, kebijakan, sikap dan tindakan sebuah masyarakat dalam hidup bernegara dengan semangat kemajemukan/keberagaman bentuk-bentuk kehidupan (sub-kultur). Subkultur tersebut antara lain seperti suku, ras, budaya ataupun agama yang mana hasil akhirnya yaitu diharapkan saling memahami dan bekerjasama mengembangkan semangat kebangsaan dan mempunyai kebanggaan untuk mempertahankan kemajemukan tersebut.

\section{Budaya Multikulturalisme}

Warisan budaya, menurut Davidson diartikan sebagai 'produk atau akibat budaya fisik dari tradisi-tradisi yang berbeda dan prestasi-prestasi spiritual dalam bentuk nilai dari masa lalu yang menjadi elemen dasar dalam jati diri suatu kelompok atau bangsa'. Jadi warisan budaya merupakan akibat budaya fisik (tangible) dan nilai budaya (intangible) dari masa lalu. ${ }^{22}$ Nilai budaya dari masa lalu (intangible heritage) inilah yang berasal dari budayabudaya lokal yang ada di Nusantara, meliputi: tradisi, cerita rakyat dan

19 Ahmad Rivai Harahap, "Multikulturalisme Dalam Bidang Sosial”, dalam Etnovisi Jurnal Antropologi Sosial Budaya, Medan: Laboratorium Pengembangan Masyarakat (LPM-ANTROP) Departemen Antropologi, Fakultas Ilmu Sosial dan Ilmu Politik, USU, vol. II, No.1, April 2006, h.34.

${ }^{20}$ Farida Hanum, dalam artikel "Multikulturalisme dan Pendidikan", h.1

21 Parsudi Suparlan, "Menuju Masyarakat Indonesia yang Multikultural”, dalam Jurnal Antropologi Indonesia, Universiatas Udayana, Bali, Juli 2002, h.96.

22 Davison, G. dan C Mc Conville. A Heritage Handbook. St. Leonard, (NSW: Allen, \& Unwin, 1992), h. 2 
legenda, bahasa ibu, sejarah lisan, kreativitas (tari, lagu, drama pertunjukan), kemampuan beradaptasi dan keunikan masyarakat setempat. ${ }^{23}$

Multikulturalisme lebih jauh merupakan konsep dimana sebuah entitas dalam hal kebangsaan dapat menghargai keragaman, perbedaan dan keragaman kultur baik ras, suku, etnis, maupun agama. Agama merupakan ekspresi budaya tentang keyakinan orang terhadap sesuatu yang suci. Kebudayaan yang ada berpengaruh pada pandangan seseorang dalam beragama. Maka sulit diterima jika seseorang dapat beragama secara murni tanpa campur tangan budaya di sekitarnya. Lingkungan kulturalnya membentuk tradisi yang sering bercampur-baur dengan pola praktik keagamaan khususnya agama yang berkaitan dengan hubungan horizontal lain halnya dengan implementasi transenden adalah urusan manusia dengan Tuhan. Maka memperdebatkan kebenaran agama yang wilayahnya lebih pada implementasi horizontal ekspresi beragama yang diyakini setiap orang, merupakan ekspresi kebudayaan yang cenderung multitafsir dan bersifat relatif atas kebenaran Tuhan yang absolut. ${ }^{24}$

Satu contoh ketika kalangan Islam memperdebatkan ekspresi kebudayaan bercorak agama pada kalangan warga NU soal Yasinan dan Tahlilan, di lain sisi kalangan Muhammadiyah tidak menjalankan ekspresi kebudayaan tersebut, maka yang dibutuhkan dua ormas Islam tersebut adalah kesadaran atas konsep multikulturalisme dari kebudayaan beragama di bumi nusantara. Sikap untuk terbuka dan saling menghargai sangat penting untuk dilakukan, mengingat sesuatu keyakinan yang ditafsir secara berbeda bias saja memicu perpecahan di masyarakat dan lebih parah lagi mengakibatkan konflik berkepanjangan. Moeslim Abdurrahman menyebut ekspresi kebudayaan umat Islam Indonesia ini dengan menyebut ber-Islam secara kultural.

\section{Sejarah Kemunculan Multikulturalisme}

Multikulturalisme telah banyak didiskursuskan oleh pelbagai pakar dalam maupun luar negeri dengan wujud tulisan-tulisan. Para pakar tersebut seperti Carl Grant, Christine Sleeter, Geneva Gay dan Sonia Nieto sarjana barat yang mendalami konsep dari pendidikan multikutural. ${ }^{25}$ Jika ditelusuri dari sejarahnya, Mun'im A Sirry di dalam artikelnya "Agama, Demokrasi, dan Multikulturalisme", dalam Kompas, 1 Mei 2003. Kemunculan multikulturalisme berdasarkan tulisan Bhikhu Parekh. Awal pergerakanya muncul di Kanada dan Australia, kemudian di Amerika Serikat, Inggris,

${ }^{23}$ Galla, A. Guidebook for the Participation of Young People in Heritage Conservation. (Brisbane: Hall and jones Advertising, 2001), h. 12

24 Moeslim Abdurrahman, Islam sebagai Kritik Sosial, (Jakarta: Penerbit Erlangga, 2003) h. 149.

25 Zubaedi, "Telaah Konsep Multikulturalisme dan Implementasinya Dalam Dunia Pendidikan", Hermeneia Jurnal, 2013, h. 6 
Jerman, dan lainnya. ${ }^{26}$ Kajian ini bermuara pada kesamaan hak di ruang publik dalam bungkusan perbedaan yang menjadi tuntutan yang harus di penuhi.

Wacana multikulturalisme di Kanada sudah muncul sejak tahun 1950. Media massa di sana banyak memuat tentang multicultural. Permasalahan multikultural dan Multilingual di masyarakat montreal saat itu, tak lain menjadi musabab isu tersebut diangkat ke atas permukaan. ${ }^{27}$ Pada tahun selanjutnya 1970, kemunculan wacana multikulturalisme sudah diletakkan dalam tataran kebijakan pemerintahan Kanada. Berdasarkan hal inilah menjadikan Kanada sebagai negara yang pertama menggagas multikulturalisme masuk dalam regulasi. ${ }^{28}$ Kelahiran kebijakan tersebut merupakan tindak lanjut tuntutan dari prinsip persamaan (egaliter) dan prinsip pengakuan (recognation) di negara tersebut (di dalam tulisan ana dan permerdi). Perjuangan atas prinsip yang disebutkan ialah pergulatan panjang oleh masyarakat pribumi suku Indian dan Eskimo. Keberlangsungan hidup yang telah menempati secara turun termurun, sejak ratusan tahun lalu walaupun sebagai masyarakat minoritas. Dan bahasa Perancis sebagai bahasa ibu mereka untuk disetarakan dengan Bahasa Inggris.

Paul Gorski menerangkan, di Amerika wacana multikulturalisme muncul sejak tahun 1960 saat diskriminasi di dalam ruang publik antara Orang Amerika keturunan Afrika dengan keturunan Amerika kulit putih dan kulit lainya. ${ }^{29}$ Dalam penuturanya, akar persoalan itu tidak lain muncul dari diskriminatif pendidikan saat itu. Diskriminasi yang dilakukan oleh dominansi masyarakat golongan kulit putih dan lainnya terhadap kulit "gelap" bukan hanya berhenti dalam pendidikan, sendi kehidupan lainya pun terancam - pekerjaan, lingkungan sosial hingga keberlangsungan hidup (lihat film dokumenter The Writer).

Dan ini mengakibatkan multikulturalisme perlu digaungkan. Perbedaan etnis, budaya, agama, dan sosial ataupun subkultural yang tergabung di dalamnya adalah akar penyebab multikulturalisme penting diperbincangkan. Lebih dari pemahaman pluralisme, kesetaraan dan pengakuan di dalam ruang publiklah menjadi fokus utama.

\section{Hasil dan Pembahasan}

\section{Sejarah Komunitas Ambengan}

Maiyah Dusun Ambengan atau biasa disebut Ambengan adalah sebuah acara diskusi kebudayaan, yang digelar rutin bulanan setiap hari Sabtu malam di

\footnotetext{
26Ibid

27 Ana Irhandayaningsih, "Kajian Filosofis., h. 4

28Pamerdi Giri Wiloso, "Multikulturalisme Dalam Perspektif Antropologi"

29 Zubaedi, “Telaah Konsep Multikulturalisme. ,h 6
}

RI'AYAH, Vol. 02, No. 01 Januari-Juni 2017 
minggu ke-2 tiap bulannya. Diskusi ini berlangsung mulai jam 20.00 WIB sampai selesai, bertempat di Rumah Hati Lampung Dusun 4 Margototo Kecamatan Metro Kibang Lampung Timur.

Ambengan adalah bagian dari tradisi 'Maiyahan'. Maiyah diisi dengan sholawat, wirid, doa, kesenian musik, dialog budaya. Orang maiyah menurut Cak Nun adalah orang hidup yang menghadapi kehidupan dengan tuntas menjalaninya, merenungi, menghayati, menangisi dan menertawakannya. Ambengan adalah bagian penerus dari tradisi musik Kiai Kanjeng dan Cak Nun di Yogyakarta yang selama ini menghidupkan dialog Kebudayaan. ${ }^{30}$ Sebagaimana Jamaah Maiyah asuhan Cak Nun seperti Padhangmbulan Jombang berlangsung setiap tanggal 15 bulan Jawa atau tepat pada saat malam bulan purnama. Mocopat Syafaat Yogyakarta dilaksanakan setiap tanggal 17. Kenduri Cinta Jakarta berlangsung setiap hari Jumat minggu kedua setiap bulannya. Dan Gambang Syafaat di Semarang setiap tanggal 25. Bangbang Wetan Surabaya berlangsung sehari sesudah Padhangmbulan. ${ }^{31}$ Ambengan melakukan pelestarian kebudayaan di tengah-tengah masyarakat dengan pertunjukan musik, dialog beragam etnis dan agama, diskusi tematik, pertunjukkan seni tari, dan lain sebagainya. ${ }^{32}$ Sebagaimana Reportase kegiatan maiyah, kegiatan Ambengan dapat diakses melalui website kenduricinta.com dan juga website Ambengan di alamat ambengan.co.

Maiyah Dusun Ambengan adalah salah satu simpul Maiyah yang ada di Lampung. Karena Syamsul Arifin atau Cak Sul adalah orang yang pernah terlibat aktif dalam acara maiyah yang diadakan oleh Emha Ainun Najib saat berada di Yogyakarta. Jadi, Maiyah Dusun Ambengan adalah replikasi dari Maiyah yang dilakukan oleh Cak Nun, dan di Lampung dipimpin oleh Syamsul Arifin.

Kegiatan ini merupakan ajang belajar bersama yang bertitel "Sinau Kebudayaan". Menyuguhkan kajian-kajian beragam tematik keilmuan, persoalan-persoalan real keseharian masyarakat terkait sosial, ekonomi, seni budaya, dan keagamaan.

Acara bersifat terbuka (untuk umum) yang dapat diikuti oleh siapa saja, dari kalangan apa saja, tanpa membedakan umur, pendidikan, profesi, suku, agama, golongan dan lain sebagainya.

Hakekat kegiatan mengutamakan kebersamaan, saling berbagi ilmu, kemesraan sosial, dan pencerahan kemanusiaan. Tidak memiliki agenda atau

30 Saputra, P. R. Spiritual Journey: Pemikiran dan Permenungan Emha Ainun Nadjib. (Jakarta: Kompas, 2012)

31 Jadwal Maiyah, di unduh tanggal 17 februari 2016 melalui https://www.caknun.com/jadwal/

32 http://www.ambengan.co/2016/01/mukadimah-reog-and-roll.html di unduh 17 Februari 2016

RI'AYAH, Vol. 02, No. 01 Januari-Juni 2017 
tujuan politik, tidak bertendensi atau berafiliasi kepada kepentingankepentingan praktis apapun, kecuali semata-mata berusaha mencari kebenaran sejati menuju martabat dan derajat kehidupan yang diridhoi Allah SWT.

Maiyah Dusun Ambengan, diinisiasi oleh sekelompok orang independen. Kegiatannya berprinsip swadaya, tidak dibiayai oleh sumber-sumber pendanaan manapun. Seluruh beban kegiatan sepenuhnya dijalani secara gotong royong bersama-sama dalam semangat keguyuban.

Tuan rumah Maiyah Dusun Ambengan adalah Rumah Hati Lampung, yang didalamnnya terdiri dari Musik Gamelan Jamus Kalimosodo, Komunitas Pendonor Darah Gratis (MonitorArtis), Sekolah Sepak Bola Anak (SSB) ASTAMA, Relawan BPJS Metro Kibang, dan sejumlah person dari berbagai lintas profesi/praktisi (pers, pendidik, seniman, enterpreneurship) yang terpanggil mendedikasikan dan mengkontribusikan skill-nya dengan sukarela. ${ }^{33}$

Dengan sangat senang hati dan kebahagiaan tidak terkira, jika seandainya forum Maiyah Dusun Ambengan dapat menarik minat siapapun untuk terlibat hadir dan melingkar bersama berpadu rasa, bersambung hati dan pikiran, dan dielaborasi kemanfaatannya bersama-sama oleh kita semua.

Oleh karenanya komunitas Ambengan selalu akan terus selalu, menyapa, memanggil, mengajak semua pihak. "Semoga kita diberikan kelapangan hati, keikhlasan tenaga, dan kelancaran langkah, niat dan tindakan, atas sebagian waktu dan umur dunia kita bergabung bersama dalam kegembiraan yang keasyikan menggapai kemuliaan bersama di Maiyah Dusun Ambengan" harapan Cak Sul.

Sebelum berdiri Ambengan, lebih dahulu sudah berjalan Musik Gamelan Jamus Kalimosodo yang merupakan musik budaya yang menggabungkan peralatan musik tradisional dan musik modern. Musik Gamelan Jamus Kalimosodo diprakarsai oleh Syamsul Arifien (Cak Sul) dan Drs. Bambang Budiyanto (Cak Babu) bersama 16 aktivis Pemuda dan Mahasiswa lainnya, lahirlah sebuah kelompok yang diberi nama "Jamus Kalimosodo" di bilangan 15A Iringmulyo Kota Metro, pada 9 Juni 1999. Adapun nama-nama aktivis pendiri itu adalah sebagai berikut:

1. Syamsul Arifien (Pekerja Sosial)

2. Drs. Bambang Budiyanto (Pekerja Sosial)

3. A. Mujib (Pekerja Sosial)

4. Mu'adin Efuari (Aktivis LSM)

5. Fadilayani (Aktivis LSM/Seniman Lokal)

6. Antoni (Seniman lokal)

7. Ruli Mondes (Seniman lokal)

33 Wawancara dengan Syamsul Arifin pimpinan Komunitas Ambengan pada 22 September 2016

RI'AYAH, Vol. 02, No. 01 Januari-Juni 2017 
8. Faid Indra Yustri, SE (Aktivis Mahasiswa)

9. Idon Sumarwan (Aktivis Pemuda)

10. Apriyadi Gunawan (Aktivis Mahasiswa)

11. Wage (Aktivis Mahasiswa)

12. Wisnu (Alm) (Aktivis Mahasiswa)

13. Isnaini Wahid (Aktivis Mahasiswa)

14. Nyoman Darmadi (Aktivis Pemuda)

15. Agus (Ateng) (Aktivis Pemuda)

16. Adi Rahmadi (Aktivis Mahasiswa)

\section{Gambar 4.1 LK II HMI se-Sumbagsel dan konpercab HMI Cabang Metro, bersama Gamelan Kiai Jamus Kalimosodo di Gedung BLK Metro Utara.}

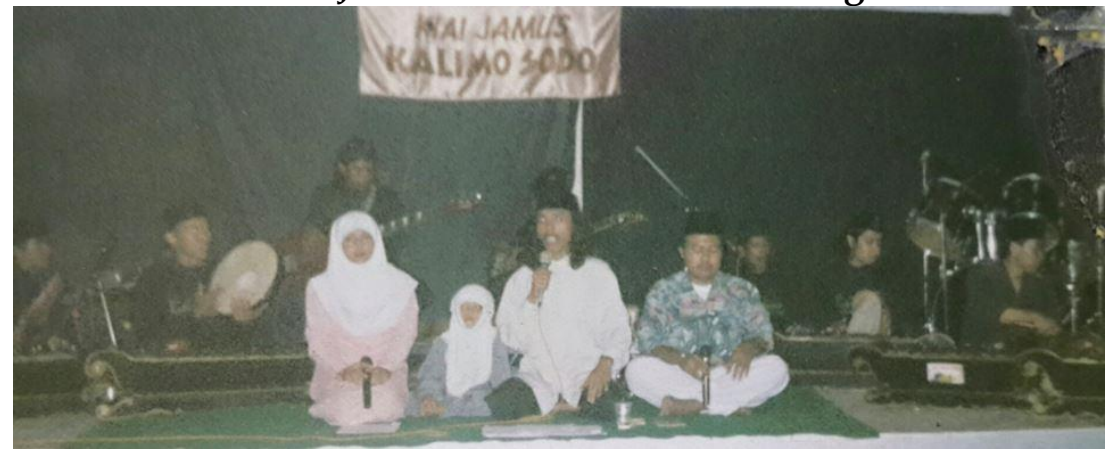

Sumber: Dokumentasi Musik Gamelan Jamus Kalimosodo

Jumlah personil musik Jamus Kalimosodo disesuaikan dengan jumlah alat yang ada, pada awal berdiri tahun 1999 saron berjumlah 7 buah, ditambah elektrik (drum, gitar bass, melodi, keyboard) sisanya sebagai vokalis. Total personil di awal berdirinya jamus kalimosodo adalah 16 orang. Visi yang dibawa oleh musik Jamus Kalimosodo adalah semangat menebar kebaikan, tidak ada motivasi materil untuk mendapatkan sesuatu dari pihak manapun.

Berdirinya Maiyah dusun ambengan merupakan pertautan sejarah, hubungan kultural dan hubungan emosional antara Jamus Kalimasada dan Maiyah yang diasuh oleh Cak Nun di Yogyakarta. Ambengan adalah salah satu simpul maiyah yang ada di Lampung yang digagas oleh Syamsul Arifin bersama teman-temannya.

Nama ambengan sendiri berasal dari literasi Jawa, disebut juga dengan berkatan atau genduren. Nasi genduren yang disebut sebagai ambeng memilki beragam komponen pembentuk seperti tumpeng, ingkung, kulupan dan berbagai komponen lain. Beragam komponen pembentuk ambeng ini yang kemudian menjadi penanda keragaman yang tidak bisa dihindari seperti halnya beragamnya kondisi masyarakat Indonesia. Ambeng tanpa beragam komponen pembentuk tidak dapat disebut dengan ambeng. Dari filosofi ambeng tersebut kemudian diambil nama ambengan yang merupakan akronim dari "ameguru bekti pangeran", artinya berbakti kepada Tuhan. Ini sesuai juga dengan semangat awal 
Jamus Kalimosodo bahwa dalam hidup harus berguru dan mengabdi kepada Tuhan. ${ }^{34}$

\section{Peran Ambengan Membangun Multikulturalisme}

Berbagai kegiatan diskusi sudah banyak digelar oleh komunitas Ambengan. berbagai tema diskusi tersebut antara lain Reog And Roll Edisi Januari 2016, Valentine Petani-Kasih Sayang, Kedaulatan Pangan Edisi Februari 2016, Gegar Kahanan Edisi Maret 2016, Emansipasi La Raiba Fih Edisi April 2016, Hardik-Harkit Nasib Edisi Mei 2016, Saya Saiman Juni 2016, K(R)Up(L)Uk Santri Edisi September 2016, Lele Minna Wa Minkum sebagai acara ulang tahun yang pertama.

Berikut ini akan peneliti sajikan kegiatan-kegiatan Ambengan yang memberikan gambaraan bagaimana multikulturalisme di bangun di Maiyah Dusun Ambengan.

\section{Ambengan dan Kajian Budaya}

Forum Ambengan merupakan kumpulan orang-orang yang ingin membicarakan ragam permasalahan yang dekat dengan kehidupan sehari-hari. Salah satu yang menjadi fokus kajian adalah soal budaya. Dalam kesempatan diskusi Ambengan yaitu pada 16 Januari 2016, Maiyah Dusun Ambengan membahas tentang kebudayaan Jawa yang dikemas dalam acara Reog and Roll.

Dalam pembukaan acara Reog and Roll tersebut, para awak Jamus Kalimosodo menghadap jamaah dan mulai memainkan tembangtembang pembuka. Lagu pertama menyapa dan menghangatkan jamaah diadaptasi dari KiaiKanjeng, Wahdana, merupakan lagu dengan syair bahasa arab.

\section{Gambar 4.2 Maiyah Dusun Ambengan dengan Tema Reog and Roll}
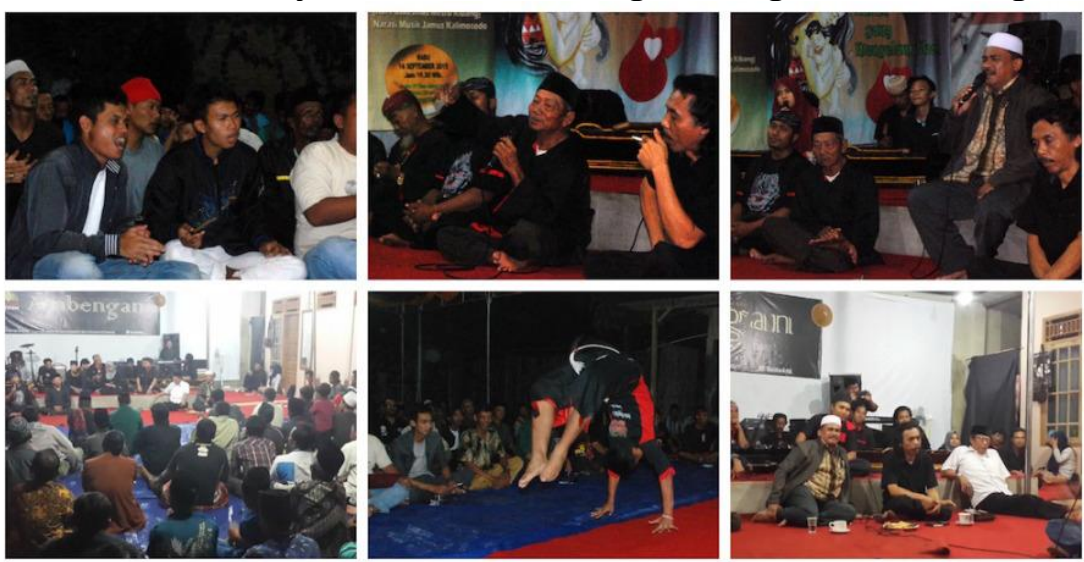

Sumber: Dokumentasi Maiyah Dusun Ambengan

${ }^{34}$ Wawancara dengan Syamsul Arifin pimpinan Komunitas Ambengan pada 24 Oktober

RI'AYAH, Vol. 02, No. 01 Januari-Juni 2017 
Suasana Maiyah Dusun Ambengan, kali ini terasa berbeda. Bukan saja terkait tema Reog and Roll, para penggiat kesenian tradisi di pedalaman Lampung itu juga banyak yang mengenakan pakaian khas Ponorogo, Jawa Timur. Terlihat hadir group reog dari Metro Selatan, Mudo Menggolo Sakti dan group Reog Margototo, Liman Singo Budoyo.

Ruang diskusi yang egaliter mampu dihadirkan Cak Sul. Jamaah fokus mendedah makna dan bagaimana para pelaku memaknai eksistensi sebagai pemain Reog. Selain tukang njatil, bujang ganong, warok dan pengasuh Reog, hadir juga Kiai Mus, bersama sejumlah santri yang ikut menyumbangkan shalawat diiringi musik Jamus Kalimosodo. Diantaranya, membawa Si'ir Tanpo Waton.

Kehadiran Kiai Mus, menjadi puncak permenungan. Selain memberi tausiah pamungkas, membawakan tembang Tombo Ati dan Lir-ilir, khidmat doa yang dipimpin pengasuh Ponpes Almutaqien Pancasila Sakti, Bandarlampung itu benar-benar menyisakan rasa dingin yang lain. Semacam tentram dan ketenangan. Puncak acara yang aneh, setelah semua jamaah menghetakkan Wirid Wabal dan musikalisasi doa taklukah 2016, lampu dipadamkan, ketenangan dan isak lembut doa-doa Kiai Mus melantun, serasa menyejukkan batin. Berbagai permohonan dalam bahasa arab dan bahasa Indonesia, khusyuk di imami Kiai Mus.

Kiai Mus yang bernama lengkap Musthofa Wagianto, sesepuh Maiyah yang sangat dekat dengan Cak Nun dan Sabrang (Noe Letto) itu lebih akrab disapa Pakde Mus. Selama ini beliau juga terlihat sering membersamai Kenduri Cinta di Jakarta.

Pergulatan mencari definisi berkesenian, mengurai makna dan mengkaji sejarah Reog, termasuk gerai tawa selama sesi diskusi dan paparan kisah, pengalaman menggeluti seni Reog oleh Pak Slamet, Mas Fitri dan atraksi warok yang dipadupadankan dengan Gamelan Jamus Kalimosodo, terasa sublim.

Mas Roko kemudian mendedah makna gemblak dalam tradisi warok. Dia menjelaskan, sejarah pertarungan antara Warok Suromenggolo dengan Warok Siman. Setelah diadu domba Surobangsat tidak bisa, mereka kemudian bertarung hidup mati hanya karena memperebutkan gemblak.

Gemblak, dalam tradisi warok itu, jelas Mas Roko, bukan soal pasangan homoseksual. Itu pandangan kuno, kasar, sebenarnya gemblak itu adalah simbol penopang ekonomi dan keberlangsungan hidup warok yang paling dasar, katanya.

Karena, lanjut dia, gemblak itu ya yang memelihara ternak, yang memasak, yang mengurus rumah tangga dan sampai yang mencuci kolor. Artinya, kalau hak dasar ekonomi direbut, warok bisa mati kelaparan dan

RI'AYAH, Vol. 02, No. 01 Januari-Juni 2017 
tanpa kehormatan. “Itu arti gemblak menurut saya, aslinya ya saya tidak tahu, wong banyak versi ceritanya", kata dia yang dengan fasih menyebut nama-nama seputar tradisi warok. Termasuk senjata bebet Suromenggolo dan Warok Siman.

Pak Slamet, sesepuh Reog di Lampung Timur lebih detil menjelaskan makna setiap pemain, arti dari kendang, kenong dan gong. Termasuk menjelaskan sanipan-sanipan atau kiasan seputar dadak merak. Bukan hanya sebagai simbol merak yang mengangkangi harimau, lebih dari itu. Sanipan dadak merak adalah potret alam semesta.

Bulu burung merak itu, diumpamakan sebagai sebuah perkampungan yang terlihat dari kejauhan. Hanya hijau dedaunan. Namun setelah didekati, bukan sekadar ada pepohonan, melainkan ada berbagai macam makhluk hidup. Selain pohon, ada rumah, ada masjid, ada manusia, ada binatang dan sebagainya. Lalu namanya barongan atau dadak merak, pasti hanya dimainkan oleh satu orang. Itu artinya, manunggal. Ada Yang Satu yang serba maha yang mengurus alam semesta ini. Tidak ada barongan Reog kok dimainkan orang dua, pasti sendirian, itulah kemanunggalan yang serba maha. Yaitu sanipan dari makna keesaan Allah SWT, kata dia.

\section{Budaya Multikulturalisme Ambengan}

Multikulturalisme ditunjukkan oleh grup musik Jamus Kalimosodo dalam acara Natal tahun 2014. Sekitar seribuan umat Kritiani Kota Metro larut dalam kegembiraan menyaksikan aksi pentas grup musik Jamus Kalimosodo di halaman parkir Stadion Tejosari Metro Timur, Sabtu 17 Januari 2015. Kehadiran grup musik pimpinan Syamsul Arifin yang biasa membawakan lagu Islami itu pada hari itu khusus untuk mengisi acara Natal Bersama.

Cak Sul, saat memandu pementasan mengajak pemuka agama nasrani, di antaranya Romo Friz, PendetaYohanes, Pastur, para aktivis Gereja serta para suster naik ke atas pentas untuk berkolaborasi membawakan Hevene Shalom Elehem, Gloria, dan Silent Nigt yang dikemas secara apik dengan perpaduan instrument gamelan khas Jamus Kalimasada. ${ }^{35}$

Ribuan Jemaat Kristiani yang memadati lokasi acara pun spontan ikut bernyanyi dan bertepuk tangan, sejak awal Jamus naik pentas hingga Cak Sul memungkasi dengan lagu Sluku Bathok.

Dalam kesempatan wawancara dengan Syamsul Arifin, pimpinan komunitas Ambengan ini mengatakan bahwa memberikan hak yang

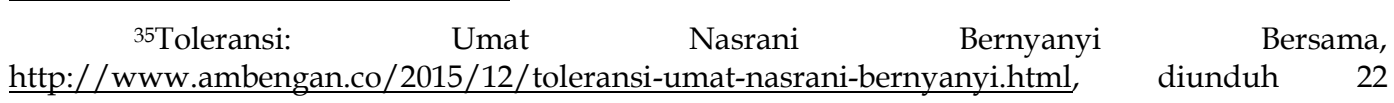


sama kepada umat kristiani untuk tampil melantutnkan lagu-lagu bernuansa budaya juga harus diberikan. Dalam suatu kesempatan, komunitas Ambengan pernah meminjamkan alat-alat musik Gamelan Jamus Kaliosodo kepada para umat kristiani. “Di situlah keber-agama-an kita diuji. Apakah kita kan menjadi umat Kristen dengan mendengarkan nyanyi-nyanyi dari umat kristiani, kan tidak to?", ujar Syamsul Arifin ${ }^{36}$.

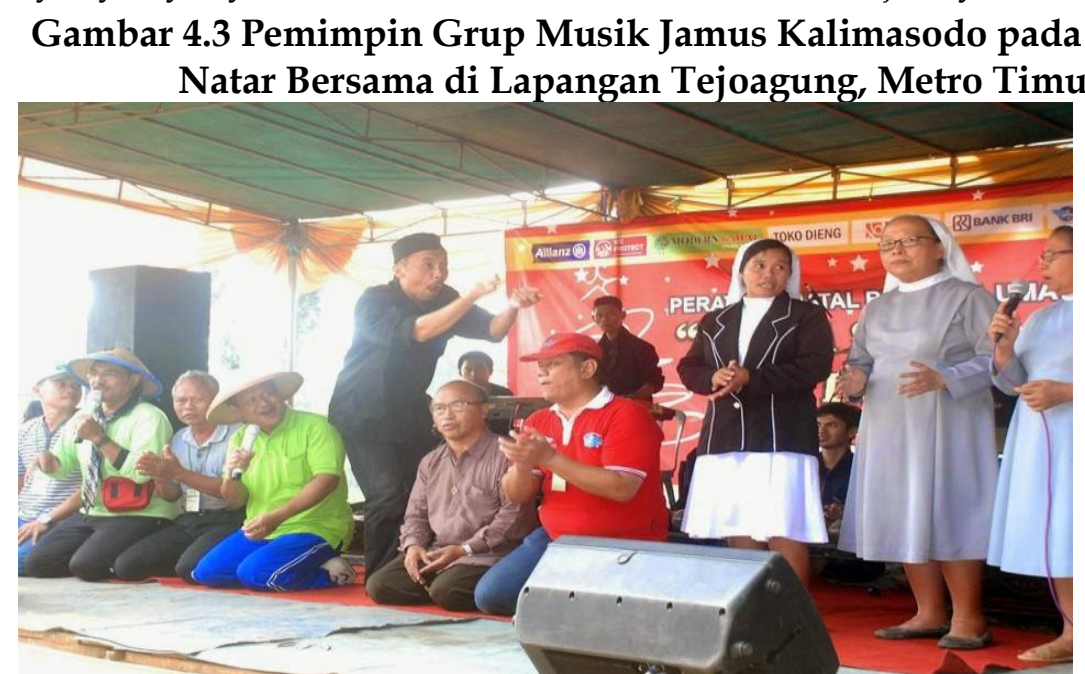

Sumber: Dokumentasi Musik Gamelan Jamus Kalimosodo

Penampilan musik Jamus Kalimosodo tidak dapat dipisahkan dari rangkaian acara Maiyah Ambengan. Sebelum acara inti, yaitu diskusi tematik yang ditentukan sebelumnya oleh pengurus Rumah Hati Lampung, Syamsul Arifin atau yang akrab dipanggil Cak Sul.

Penampilan musik Gamelan Jamus Kalimosodo seperti pada acara yang dibesut oleh perusahaan tambak udang PT Centralpertiwi Bahari bekerjasama dengan Dewan Kesenian Lampung dan FISIP Universitas Lampung siap menghadirkan budayawan Emha Ainun Nadjib (Cak Nun) untuk menjadi penampil utama dalam acara "Sekala Selampung"37.

Acara yang dilaksankan sabtu tanggal 16 November 2013 di lapangan Korpri depan kantor Gubernur/DPRD Lampung di Bandarlampung mulai pukul 19.00 WIB hingga selesai.

Arman menegaskan bahwa tanah Lampung yang kaya secara ekonomi juga kaya dan dinamis secara sosial budaya sebagai miniaturnya Indonesia. "Harmoni dan kebersatuan di Lampung adalah simbolisasi harmoni dan kebersatuan di Indonesia," katanya. Ikram Baadillah dari FISIP Unila mengemukakan bahwa di tengah gencarnya pembangunan

2016

36Wawancara dengan Syamsul Arifin pimpinan Komunitas Ambengan pada 24 Oktober ${ }^{37}$ Cak Nun penampil utama "Sekala Selampung", http://www.antaranews.com/berita/404755/cak-nun-penampil-utama-sekala-selampung, diunduh pada 22 September 2016

RI'AYAH, Vol. 02, No. 01 Januari-Juni 2017 
ekonomi sudah seharusnya pembangunan aspek sosial budaya juga ditingkatkan, sehingga aspek spiritual dan kekayaan budaya lokal tidak akan tergerus. Semua wajib menjaga identitas kebangsaan melalui perawatan tradisi lokal yang harus menjadi perhatian semua pihak.

Sebagai bentuk penghargaan untuk adat Lampung maka di saat acara "Ngaji Bersama Santri, Tokoh Dan Masyarakat Kabupaten Pesawaran Lampung" secara seremonial tari adat Lampung diberika kesempatan untuk tampil. Beberapa sesi penampilan Tari Adat Lampung, Hadroh, dan Marawis Al Farabi yang berkolaborasi degan Jamus Kalimosodo. Seperti dimaiyah-maiyah lainnya, Cak Sul dibantu Mas Baim mempersilahkan naik ke panggung kepada para Tokoh Masyarakat, Pimpinan Pondok Pesantren Al Farabi, Kapolsek Negri Katon, perwakilan Kapolres Pesawaran, perwakilan DPRD Pesawaran, Perwakilan Bupati, Kades Halangan Ratu, termasuk pembicara utama acara ini yaitu Ustadz Noorsofa Thohir dari Jakarta yang kerap hadir menjadi pembicara di Simpul Maiyah Kenduri Cinta.

\section{Gambar 4.4 Ngaji Bersama Santri, Tokoh Dan Masyarakat Kabupaten} Pesawaran Lampung

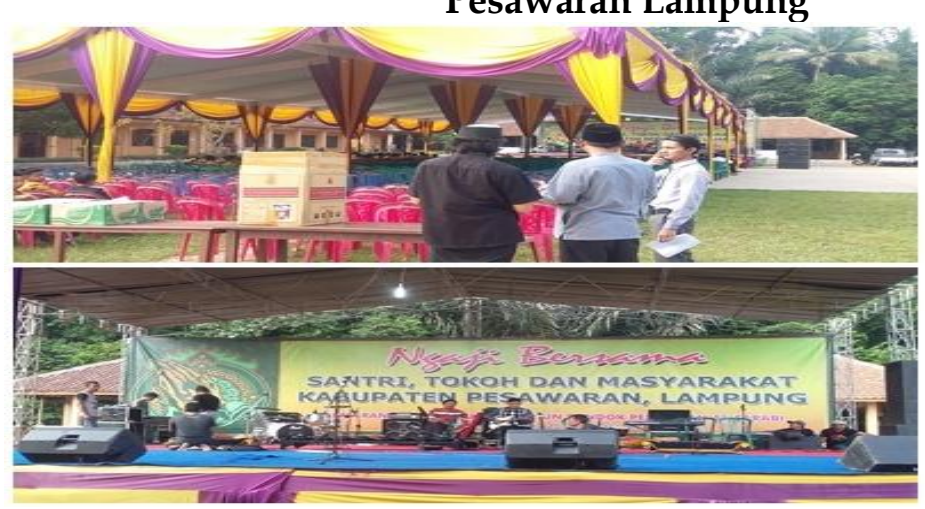

Dokumentasi Maiyah Dusun Ambengan

Multikulturalisme terdiri atas tiga komponen, yakni kebudayaan, pluralitas kebudayaan, dan cara tertentu untuk merespons pluralitas itu. Multikulturalisme bukanlah doktrin politik pragmatik, melainkan cara pandang kehidupan manusia. Karena hampir semua negara di dunia tersusun dari aneka ragam kebudayaan artinya perbedaan menjadi asasnya dan gerakan manusia dari satu tempat ke tempat lain di muka bumi semakin intensif, maka multikulturalisme itu harus diterjemahkan ke dalam kebijakan multikultural sebagai politik pengelolaan perbedaan kebudayaan warga negara. Setidaknya ada tiga model kebijakan multikultural negara untuk menghadapi realitas pluralitas kebudayaan.

Multikulturalisme lebih jauh merupakan konsep dimana sebuah entitas dalam hal kebangsaan dapat menghargai keragaman, perbedaan dan keragaman kultur baik ras, suku, etnis, maupun agama. Agama merupakan ekspresi budaya 
tentang keyakinan orang terhadap sesuatu yang suci. Kebudayaan yang ada berpengaruh pada pandangan seseorang dalam beragama. Maka sulit diterima jika seseorang dapat beragama secara murni tanpa campur tangan budaya di sekitarnya. Lingkungan kulturalnya membentuk tradisi yang sering bercampurbaur dengan pola praktik keagamaan khususnya agama yang berkaitan dengan hubungan horizontal lain halnya dengan implementasi transenden adalah urusan manusia dengan Tuhan. Maka memperdebatkan kebenaran agama yang wilayahnya lebih pada implementasi horizontal ekspresi beragama yang diyakini setiap orang, merupakan ekspresi kebudayaan yang cenderung multitafsir dan bersifat relatif atas kebenaran Tuhan yang absolut.

Acara yang digelar menghadirkan narasumber dari berbagai latar belakang. Misalnya pada saat acara "Saya Saiman", narasumber adalah seorang lelaki paruh baya bernama Saiman yang berprofesi sebagai tukang sapu. Jadi siapa saja bisa menjadi guru dan dapat dihadirkan di forum disksusi Ambengan.

Menurut Syamsul Arifin, dengan menghadirkan narasumber dari beragam latar belakang, harapannya acara dapat pula dihadiri banyak kalangan. Memang benar kemudian, strategi ini berhasil menghadirkan peserta dari beragam latar belakang profesi, agama suku.

Tomi Nurrohman memberikan pandangan terhadap komunitas Maiyah Dusun Ambengan. “Komunitas Ambengan adalah komunitas kebudayaan yang konsisten menyuarakan keberagaman. Saya fikir diusia yang sekarang, komunitas ini mampu membangun multikulturalisme dengan strategi budaya seperti penampilan reog, tari Lampung, gitar tinggal Lampung, pemanfaatan gamelan Jawa sebagai alat pengiring music yang di manfaatkan oleh musik Gamelan Jamus Kalimosodo. Artinya, ada kesempatan yang sama yang diberikan kepada seniman Lampung untuk menampilkan pula kebudayaan masyarakat Lampung sebagai suku asli", ujar Tomi ${ }^{38}$.

\section{Peran Ambengan Mereduksi Akar Konflik di Lampung Timur}

Sebagai komunitas budaya, ambengan mengajak para pegiat dan masyarakat umum untuk selalu membuka ruang dialog yang mengangkat beragam tema. Tema-tema yang disetujui oleh pengurus komunitas ambengan kemudian menjadi pembahasan yang mendatangkan narasumber sesuai dengan tema. Upaya mereduksi konflik salah satunya dilakukan dengan memanfaatkan ambengan sebagai komunitas budaya untuk membuka ruang dialog.

\section{Emansipasi La Raiba Fih}

Tema Emansipasi La Raiba Fih, 16 April 2016, digagas seiring dengan peringatan hari Kartini, 21 April, ternyata mampu memiliki dampak kejut

38 Wawancara dengan Tomi Nurrohman anggota Komunitas Ambengan pada 24 November 2016

RI'AYAH, Vol. 02, No. 01 Januari-Juni 2017 
yang luar biasa. Mengejawantah dengan menyulut kesadaran kaum ibu di Desa Margototo dan desa-desa sekitar, bahkan secara umum di Lampung Timur dan Provinsi Lampung untuk benar-benar terlibat.

Teridentifikasi bahwa jamaah yang mengikuti Maiyah Ambengan mulai beragam, berasal dari berbagai wilayah Lampung Timur seperti kecamatan Batanghari, Pekalongan, Purbolinggo, Way Jepara, Braja Selebah, Mataram Baru, Sribawono, Sekampung Udik, Sekampung. Juga jamaah dari Kabupaten/Kota provinsi Lampung antara lain Kota Metro, Bandar Lampung, Kabupaten Lampung Selatan, Lampung Tengah, Lampung Barat, dan Tanggamus.

\section{Gambar 4.4 Jamaah Maiyah Dusun Ambengan edisi April 2016}
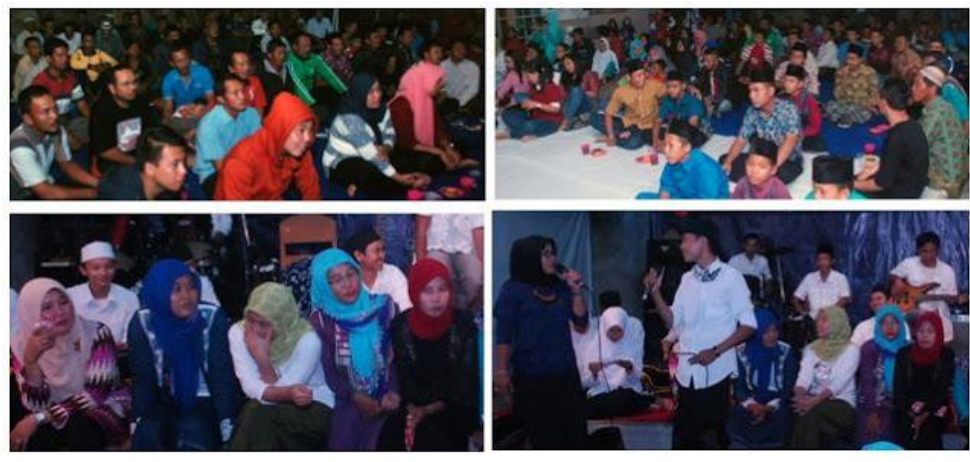

Dokumentasi Maiyah Dusun Ambengan

Bu Tri, sebagai pembicara pertama mengaku, tugas utamanya, ibu rumah tangga tapi punya tugas tambahan yang juga tak kalah serius ketika mengerjakannya. Yakni, mengajar di SMA Negeri 1 Metro Kibang.

$\mathrm{Bu}$ Tri menceritakan pentingnya paham dan masuk ke dunia masa kini. Seperti soal hape. Ponsel anak saya itu isinya apa saja, saya harus tahu dan mau belajar. Memaknai emansipasi, menurut dia sangat penting terutama dalam kaitan menguasai tekhnologi. Akan tetapi jangan salah, Kartini di desa itu, meski punya aktivitas di luar rumah, bangun tidur sudah menyiapkan sarapan, kopi berikut baju. "Sak sempak-sempake, disiapne." Semua demi melayani dan menetapi kodrat sebagai istri dan ibu bagi anak-anaknya. Semua disiapkan. Kalau laki-laki, berangkat kerja ya langsung berangkat saja. Ini bedanya. 


\section{Gambar 4.5 bu Tri Gunawan guru SMA, Jemaat Gereja Santo Bantul Kota Metro, Mbak Khoir Ketua Bawaslu Lampung, Ibu Kartini,} pedagang sayur
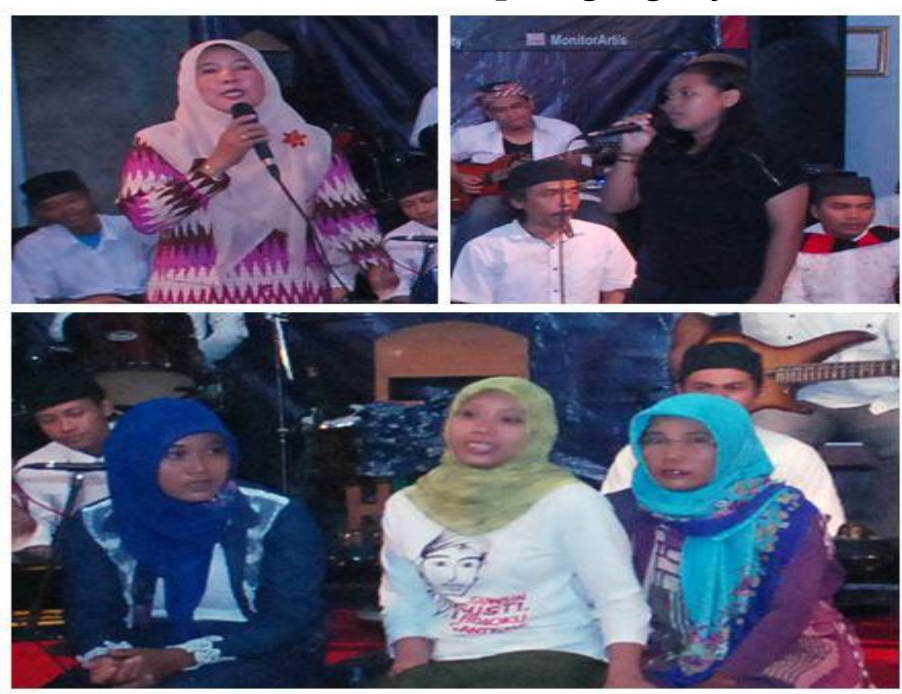

Dokumentasi Maiyah Dusun Ambengan

Sekadar memberikan rangkuman pemahaman atas emansipasi dan banyak mengeksplore perjuangan Kartini-Kartini desa masa kini. Fatikhatul Khoiriyah yang merupakan Ketua Bawaslu Provinsi Lampung, justru terlibat menceritakan kemurungan. "Saya juga lahir di desa, namanya Desa Teluk Dalam, Kecamatan Mataram Baru, Lampung Timur. Ibu saya sama dengan Mbokde Kartini, dagang di pasar yang jauh. Berangkatnya subuh. Beliau adalah Kartini, pejuang bagi kehidupan saya, alhamdulillah bisa menyekolahkan saya," ujarnya.

Mbak Khoir yang kedua kalinya membersamai Maiyah Dusun Ambengan ini mengaku bangga, duduk bersama Kartini-Kartini desa yang luar biasa. Kartini-Kartini yang sesungguhnya dan ada sebagai bukti perempuan bukan sekadar kanca wingking. Bukan wanita yang bermakna wani ditata. Melainkan, wani menata. Lebih sebagai penata rumah tangga, penata kehidupan, penata semesta untuk benar-benar harmoni.Emansipasi itu, menurut fatikhatul Khoriyah, tidak serta merta kesamaan dengan lelaki. Kalau lelaki nyangkul, perempuan tidak perlu sama haru bisa nyangkul. Melainkan potensi yang mampu berperan ganda yang fungsinya saling melengkapi.

\section{Babad Desa}

Tidak seperti biasa, majelis Ambengan pada Sabtu, 15 Oktober 2016 malam memakai tenda agar jamaah bisa tenang melingkar, bergembira dengan shalawat yang dibawakan awak musik Jamus Kalimasada, serta bernostalgia mencari akar pohon sejarah tentang terbentuknya desa-desa di Kecamatan Metro Kibang, kawasan yang disebut sebagai "kidul kali". 
Sebuah panggilan yang bernada olok-olok, ejekan dan membuat yang dipanggil merasa rendah diri.

Duduk tertib di depan menghadap jamaah, para tetua kampung yang semuanya sudah dipanggil dengan sebutan Mbah atau Kakek. Hadir sebagai nara sumber beberapa sesepuh desa, Mbah Senen, Mbah Slamet, Mbah Mangun serta sejumlah tokoh yang tahu sejarah awal berdirinya desa-desa di wilayah Metro Kibang.

Istilah babad desa, menurut Pak Suswanto bisa diartikan macammacam, dan semuanya mempunyai kadar kebenarannya sesuai konteksnya masing-masing. Kalau ada yang mengartikan babad itu sebagai jeroan sapi ya ndak masalah, karena itu juga namanya babad. Kalau rumput depan rumah kita bongkor, pun perlu dibabad (dipangkas/dibersihkan). Selanjutnya Pak Suswanto menyinggung beberapa sebutan desa di Lampung, ada pekon, dukuh, kampung, desa atau deso. "Tapi awake dewe iki penake nyebute yo deso wae".

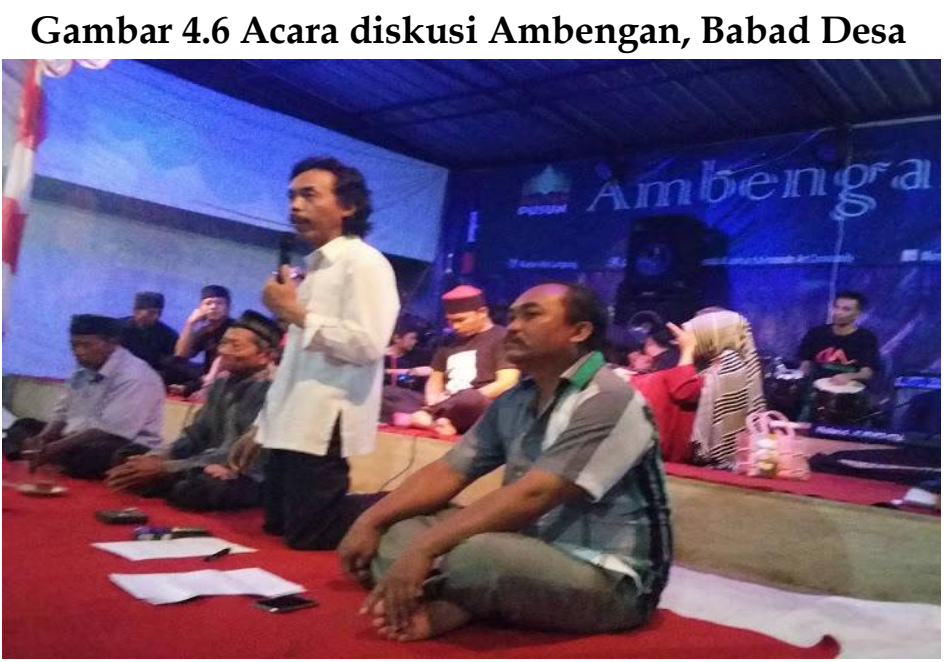

Dokumentasi Maiyah Dusun Ambengan

"Jadi boleh-boleh saja begitu kita masing-masing memberi mengartikan tergantung konteksnya kita sedang bicarakan apa. Di dalam maiyahan seperti ini ilmu-ilmu terurai dengan luas, kita mendapatkannya dengan rileks, tanpa kehilangan keseriusan, dan hati kita bahagia", tutur Pak Suswanto

Pada proses penyelesaian konflik, konflik diselesaikan melalui pendekatan kebudayaan dan adat istiadat yang berlaku. Kebudayaan dianggap mewakili komunitas tertentu. Sistem budaya itu sendiri adalah seperangkat pengetahuan meliputi pandangan hidup, keyakinan, nilai, norma, aturan, hukum yang menjadi milik satu masyarakat melalui proses belajar, yang kemudian diacu sebagai pedoman untuk menata, menilai, dan menginterpretasikan sejumlah benda dan peristiwa dalam beragam aspek kehidupan dalam lingkungan masyarakat yang bersangkutan. Keseluruhan unsur diatas menjadi "roh" bagi

RI'AYAH, Vol. 02, No. 01 Januari-Juni 2017 
kehidupan dalam masyarakat. Pola hidup sampai pada proses penyelesaian konflik pun melibatkan nilai-nilai kebudayaan didalamnya.

Kebudayaan menjadi sesuatu yang sangat penting bagi komunitas satu maupun komunitas lain diluarnya. Bagi komunitas lain diluarnya, hal ini menjadi "pintu" untuk memasuki dan mempelajari komunitas tertentu. Kebudayaan menjadi dasar untuk bertingkah laku dalam masyarakat dan juga untuk menghindari konflik. Namun, apabila konflik tidak dapat dihindarkan maka nilai-nilai kebudayaan akan kembali digunakan sebagai proses penyelesaian masalah.

Kebudayaan juga digunakan sebagai upaya preventif untuk mereduksi konflik-konflik yang bisa terjadi kapan saja. Dalam upaya mencegah preventif konflik yang ada di Lampung Timur, Syamsul Arifin mengatakan bahwa yang memilki otoritas adalah pemerintah daerah. Tapi sebagai masyarakat dan komunitas di Lampung Timur, Ambengan harus ikut berperan aktif untuk melakukan dialog-dialog. "Konflik sudah terjadi sejak Nabi Adam melahirkan dua anak. Tapi bagimanana kita mengeliminir diri sendiri untuk tidak masuk dalam konflik adalah hal kecil yang bisa dilakukan.", ujar Syamsul. ${ }^{39}$

Bagaimana menjadi manusia yang sadar dengan sifat kemanusiaannya itu penting, itu yang tidak akan pernah selesai dalam proses belajar manusia. Apakah Kemanusiaan seseorang semakin baik atau tidak. Inti dari manusia itu adalah belajar kemanusiaan. Belajar kemanusiaan tidak akan pernah selesai dalam kehidupan manusia, belajar sepanjang hayat.

Dharma Setyawan menilai bahwa apa yang dilakukan oleh komunitas Ambengan adalah upaya preventif pencegahan konflik di Lampung Timur. "Berdialog dengan memanfaatkan seni budaya sebagai sarana adalah hal menarik yang dilakukan oleh komunitas ini untuk membicaraan soal keberagaman", ujar Dharma. ${ }^{40}$

Strategi reduksi konflik ini dilakukan oleh Syamsul Arifin bersama dengan Komunitas Maiyah Ambengan dengan memanfaatkan diskusi budaya sebagai mediumnya. Dimana budaya sebagai salah satu nilai yang dipegang teguh oleh masyarakat menjadi bagian penting dari pencegahan konflik yang terjadi.

Pelibatan berbagai pihak dalam acara ambengan adalah strategi yang dilakukan Syamsul Arifin untuk mengajak masyarakat bersikap egaliter kepada sesama manusia sehingga tidak membeda-bedakan antara satu dengan yang lain.

39 Wawancara dengan Syamsul Arifin pimpinan Komunitas Ambengan pada 24 Oktober 2016

40Wawancara dengan Dharma Setyawan pemerhati Komunitas Ambengan pada 25 November 2016

RI'AYAH, Vol. 02, No. 01 Januari-Juni 2017 


\section{Kesimpulan}

Penelitian ini memberikan gambaran tentang bagaimana Komunitas Maiyah Dusun Ambengan menjadikan kebudayaan sebagai sarana membuka ruang dialog untuk beragam suku, agama, etnis dan pemikiran untuk berkumpul dan berdiskusi secara egaliter. Komunitas Ambengan menggunakan budaya sebagai sarana multikulturalisme dengan menghadirkankan banyak pihak agar membiasakan rembuk/berdiskusi sebagai sarana dengar pendapat.

Kebudayaan juga digunakan sebagai upaya preventif untuk mereduksi konflik-konflik yang bisa terjadi kapan saja. Dalam upaya mencegah preventif konflik yang ada di Lampung Timur, Maiyah Dusun Ambengan sebagai komunitas di Lampung Timur, ikut berperan aktif untuk melakukan dialog-dialog. Pada akhirnya sebelum konflik terjadi, tindakan preventif pencegahan konflik sudah dilakukan dengan membuka ruang-ruang dialog bernuansa budaya.

\section{Referensi}

Baso, Ahmad. 2005 Islam Pasca Kolonial: Perselingkuhan Agama, Kolonialisme, dan Liberalisme. Bandung: Mizan

Harahap, Ahmad Rivai. 1 April 2006. Multikulturalisme Dalam Bidang Sosial", dalam Etnovisi Jurnal Antropologi Sosial Budaya, Medan: Laboratorium Pengembangan Masyarakat (LPM-ANTROP) Departemen Antropologi, Fakultas Ilmu Sosial dan Ilmu Politik, USU. vol. II, No.

Irhandayaningsih, Ana. Kajian Filosofis Terhadap Multikulturalisme Indonesia

Ariestha, Bethra. 2013. Akar Konflik Kerusuhan Antar Etnik Di Lampung Selatan (Studi Pada Kerusuhan Antar Etnik Lampung dan Etnik Bali di Lampung Selatan). Skripsi. Jurusan Psikologi Fakultas Ilmu Pendidikan Universitas Negeri Semarang

Huddart, David. 2006. Homi K. Bhabha, London \& New York, Routledge.

Davison, G. dan C Mc Conville. 1992. A Heritage Handbook. St. Leonard, NSW: Allen, \& Unwin,

Najib, Emha Ainun, 2007. Orang Maiyah: Terang dalam kegelapan Kaya dalam Kemiskinan. Yogyakarta: Progress

Hanum, Farida. dalam artikel Multikulturalisme dan Pendidikan

Galla, A. 2001. Guidebook for the Participation of Young People in Heritage Conservation. Brisbane: Hall and jones Advertising

Geertz, C. 1966. Religion as a Cultural System. Dalam Anthropological Approaches to the Study of Religion. (Di-edit oleh Michael Banton). London: Tavistock

Hadiwinoto, S. 2002. Beberapa Aspek Pelestarian Warisan Budaya. Makalah disampaikan pada Seminar Pelestarian dan Pengembangan Masjid Agung Demak, di Demak, 17 Januari

Koentajaraningrat. 1980. Pengantar Ilmu Antropologi. Jakarta: Aksara Baru.

Koentjaraningrat. 1988. Ilmu Antropologi. Jakarta: Bhratara.

Kymlicka, W. 1995. Multicultural Citicenship: Liberal theory of Minority Rights. Oxford: Clarendon Press

Humaedi, M. Alie. Kegagalan Akulturasi Budaya Dan Isu Agama Dalam Konflik Lampung, Jurnal “Analisa” Volume 21 Nomor 02 Desember 2014 
Humaedi, M. Alie. 2013. Konflik Komunal Lampung-Bali: Anatomi dan Pemicu Konflik. Laporan Penelitian. Jakarta: LIPI

Moeslim Abdurrahman, Islam sebagai Kritik Sosial, (Jakarta: Penerbit Erlangga, 2003) h. 149.

Wiloso, Pamerdi Giri. Multikulturalisme Dalam Perspektif Antropologi

Parekh, B. 2000. Rethinking Multiculturalism: Cultural diversity and Political Theory, MacMillan: Press Ltd,

Suparlan, Parsudi. 2002. "Menuju Masyarakat Indonesia yang Multikultural", dalam Jurnal Antropologi Indonesia, Universiatas Udayana, Bali, Juli

Sadewo, Putut Ary. 2014. Dinamika Konflik Agraria dalam kehidupan sosial Masyarakat Sendangayu dan Surabaya Kecamatan Padangratu, (Tesis Pascasarjana Pendidikan IPS Fakultas Keguruan dan Ilmu Pendidikan Universitas Lampung

Saputra, P. R. 2012. Spiritual Journey: Pemikiran dan Permenungan Emha Ainun Nadjib. Jakarta: Kompas

Supardi Suparlan. (1988). kata pengantar dalam Buku, Agama: Dalam Analisa Dan Interpretasi Sosiologis (Di-edit oleh Ronald Robertson). Jakarta: Rajawali,

Zubaedi. 2013 . Telaah Konsep Multikulturalisme dan Implementasinya Dalam Dunia Pendidikan, Hermeneia Jurnal,

Website

Cak Nun penampil utama "Sekala Selampung", http://www.antaranews.com/berita/404755/cak-nun-penampil-utamasekala-selampung, diunduh pada 22 September 2016

http://www.ambengan.co/2016/01/mukadimah-reog-and-roll.html di unduh 17 Februari 2016

http://www.ambengan.co/2016/01/mukadimah-reog-and-roll.html di unduh 17 Februari 2016

Jadwal Maiyah, di unduh tanggal 17 februari 2016 melalui https://www.caknun.com/jadwal/

Toleransi: Umat Nasrani Bernyanyi Bersama, http://www.ambengan.co/2015/12/toleransi-umat-nasranibernyanyi.html, diunduh 22 September 2016

\section{Wawancara}

Wawancara dengan Dharma Setyawan pemerhati Komunitas Ambengan pada 25 November 2016

Wawancara dengan Syamsul Arifin pimpinan Komunitas Ambengan pada 24 Oktober 2016

Wawancara dengan Syamsul Arifin pimpinan Komunitas Ambengan pada 22 September 2016

Wawancara dengan Tomi Nurrohman anggota Komunitas Ambengan pada 24 November 2016 